\title{
Divalent Metal Ion-Peptide Interactions Probed by Electron Capture Dissociation of Trications
}

\author{
Haichuan Liu and Kristina Håkansson \\ Department of Chemistry, University of Michigan, Ann Arbor, Michigan, USA
}

Electron capture dissociation (ECD) of the peptide Substance P (SubP) complexed with divalent metals has been investigated. ECD of $[\mathrm{SubP}+\mathrm{H}+\mathrm{M}]^{3+}\left(\mathrm{M}^{2+}=\mathrm{Mg}^{2+}-\mathrm{Ba}^{2+}\right.$ and $\mathrm{Mn}^{2+}-\mathrm{Zn}^{2+}$ ) allowed observation of a larger number of product ions than previous investigations of doubly charged metal-containing peptides. ECD of $\mathrm{Mg}-\mathrm{Ba}, \mathrm{Mn}, \mathrm{Fe}$, and $\mathrm{Zn}$-containing complexes resulted in product ions with and without the metal from cleavage of backbone amine bonds ( $c^{\prime}$ and $z$-type ions). By contrast, ECD of Co and Ni-containing complexes yielded major bond cleavages within the C-terminal methionine residue (likely to be the metal ion binding site). $\mathrm{Cu}$-containing complexes displayed yet another behavior: amide bond cleavage ( $b$ and $y^{\prime}$-type ions). We believe some results can be rationalized both within the hot hydrogen atom mechanism and mechanisms involving electron capture into excited states, such as the recently proposed amide superbase mechanism. However, some behavior, including formation of $\left(c_{n}{ }^{\prime} \mathrm{M}-\mathrm{H}\right)^{+}$ions for $\mathrm{Ca}-\mathrm{Ba}$, is best explained within the latter mechanisms with initial electron capture at the metal. In addition, the ECD behavior appears to correlate with the metal second ionization energy (IE2). Co and Ni (displaying sequestered fragmentation) have IE2s of 17.1 and $18.2 \mathrm{eV}$, respectively, whereas IE2s for Mg-Ba, Mn, and Fe (yielding random cleavage) are 10.0 to $16.2 \mathrm{eV}$. This behavior is difficult to explain within the hot hydrogen atom mechanism because hydrogen transfer should not be influenced by IE2s. However, the drastically different fragmentation patterns for $\mathrm{Co}, \mathrm{Ni}$, and $\mathrm{Cu}$ compared to the other metals can also be explained by their higher propensity for nitrogen (as opposed to oxygen) binding. Nevertheless, these results imply that directed fragmentation can be accomplished via careful selection of the cationizing agent. (J Am Soc Mass Spectrom 2006, 17, 1731-1741) (c) 2006 American Society for Mass Spectrometry

$\mathrm{I}$ nteractions of divalent metal ions $\left(\mathrm{M}^{2+}\right)$ with biological molecules, including nucleic acids and proteins, are essential to many biological processes [1-4]. For example, $\mathrm{Ca}^{2+}$-binding proteins (e.g., calmodulin) are involved in cellular processes in which $\mathrm{Ca}^{2+}$ acts as an intracellular secondary messenger [5]. Other processes, including respiration and gene regulation, require the presence of specific metal ions [2-4]. Divalent metal ions also play an active role in enzyme action and redox reactions [6, 7]. Furthermore, metal ions may induce structural or conformational changes of peptides and proteins by interacting with carbonyl groups and/or amide groups as well as side chains of amino acid residues, resulting in important structural and catalytic properties [8,9].

Gas-phase characterization of metal ion-molecule interactions can reveal the intrinsic properties of such interactions in the absence of solvation and counter ion effects. Intrinsic interactions of divalent metal ions with

Published online September 6, 2006

Address reprint requests to Dr. K. Håkansson, Department of Chemistry, University of Michigan, 930 N. University Ave., Ann Arbor, MI 48109-1055, USA. E-mail: kicki@umich.edu amino acids [10], peptides [11-22], and proteins [17, 18, 23-25] have been extensively characterized in the gas phase by different techniques, including collision activated dissociation (CAD), ion mobility mass spectrometry, and hydrogen/deuterium exchange. For example, Gross and coworkers performed CAD of $\mathrm{Ca}^{2+}$ complexes with peptide analogs of the calcium binding-site III of rabbit skeletal troponin $\mathrm{C}$ and found that $\mathrm{Ca}^{2+}$ is bound to deprotonated acidic sites and carbonyl oxygens [14]. Other experiments by Kothani et al. have shown that alkali metal ions can enhance the helicity of gas-phase polyalanine peptides (e.g., $\mathrm{Ala}_{20}$ ), while complexation with divalent metal ions $\left(\mathrm{M}^{2+}=\mathrm{Mg}^{2+}-\mathrm{Ba}^{2+}\right)$ results in disruption of $\mathrm{Ala}_{\mathrm{n}}$ helicity due to the stronger interactions between alkali earth metal ions and the $\mathrm{Ala}_{\mathrm{n}}$ C-terminus and carbonyl groups [13].

Since it appeared in 1998 [26], electron capture dissociation (ECD) has been shown to be a powerful tool for sequencing peptides and proteins, determining sites of posttranslational modifications (PTMs), understanding protein folding, and distinguishing isomeric peptides [27-30]. ECD is complementary to traditional MS/MS methods, such as CAD, in that $\mathrm{N}-\mathrm{C}_{\alpha}$ and $\mathrm{S}-\mathrm{S}$ bonds are cleaved, the former resulting in $c^{\prime}$ - and $z$-type 


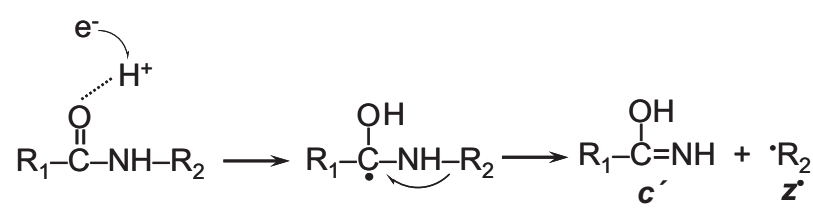

Scheme 1. The hot hydrogen mechanism for ECD of peptides. Electron capture at a charge center (solvated to carbonyl groups) is followed by hydrogen atom transfer to a backbone carbonyl, resulting in cleavage of $\mathrm{N}-\mathrm{C}_{\alpha}$ bonds.

ions [31, 32], without loss of labile PTMs [27-30]. Although ECD has been successfully applied to analyze intact proteins $[33,34]$, its detailed mechanism is still an active controversy for both experimentalists and theoretists [27, 35-46]. In one of the proposed peptide ECD mechanisms $[29,36,41]$, neutralization is thought to occur at a charge center $\left(\mathrm{H}^{+}\right)$(solvated to, e.g., carbonyl groups), which releases a hydrogen atom that is subsequently captured by a backbone carbonyl group, forming an aminoketyl intermediate. This intermediate can then dissociate into $c^{\prime}$ and $z^{\prime}$ ions via cleavage of the adjacent $\mathrm{N}-\mathrm{C}_{\alpha}$ bond, see Scheme $\mathbf{1}$. We will refer to this mechanism as the hot hydrogen mechanism.

In alternative mechanisms, the electron has been proposed to be captured in electronically excited states $[42,46,47]$. Simons and coworkers showed computationally that Coulomb stabilization (by protons or other positive charges) of peptide amide $\pi^{*}$ orbitals renders them amenable to exothermic electron attachment [45]. Such direct electron capture by peptide backbone amide groups is attractive because it explains the random nature of ECD in that there is very limited preference for cleavage at particular amino acid residues. The amide superbase mechanism (see Scheme 2), recently proposed by Syrstad and Turecek [46], includes proton transfer (due to the high basicity of the excited amide) following electron capture, which also accounts for the hydrogen transfer event observed in ECD. These authors proposed that the amide superbase mechanism can act in conjunction with a hot hydrogen like mechanism. In addition, they suggested that the presence of a metal ion may facilitate proton transfer to amide groups because the acidity of alpha carbons increases upon metal association. However, to date, only limited information on ECD of metal adducted peptides and proteins has been obtained [43, 48-50].

Williams and coworkers [43] investigated ECD and CAD of [peptide $+\mathrm{nH}]^{n+}(n=2-5)$, [peptide $+\mathrm{H}+$ $\mathrm{M}]^{2+}$, and [peptide $\left.+2 \mathrm{M}\right]^{2+}(\mathrm{M}=\mathrm{Li}$ or Cs $)$ and found that fragmentation of [peptide $+2 \mathrm{M}]^{2+}$ was analogous to that of [peptide $+2 \mathrm{H}]^{2+}$. ECD of [peptide $+\mathrm{H}+$ $\mathrm{Li}^{2+}$ and [peptide $\left.+\mathrm{Li}+\mathrm{Cs}\right]^{2+}$ revealed that neutralization occurred at the cation with the highest recombination energy $\left(\mathrm{H}^{+}>\mathrm{Li}^{+}>\mathrm{Cs}^{+}\right)$. Kellersberger and Fabris found that chelation of metal dications to EFhands and zinc fingers in model peptides resulted mainly in ECD fragmentation close to the chelating residues [49]. Recently, Chan and coworkers and Kleinnijenhuis et al. investigated ECD of doubly charged peptide-metal dication complexes [48, 50]. For different alkaline earth metals, very similar ECD spectra were observed for two model peptides [48] whereas ECD of transition-metal adducts to the peptide hormone oxytocin generated strikingly different spectra, including atypical product ions [50]. However, the information obtained regarding ECD of such complexes was incomplete due to the observation of a limited number of product ions. Here, we present ECD of triply charged complexes between a series of metal dications and Substance $\mathrm{P}$ (SubP), [SubP $+\mathrm{H}+\mathrm{M}]^{3+}$, in which $\mathrm{M}=\mathrm{Mg}-\mathrm{Ba}$ and $\mathrm{Mn}-\mathrm{Zn}$. ECD of triply protonated SubP was also investigated. These experiments provided some insights into the ECD mechanism and allowed a more rigorous characterization of the fragmentation behavior of metal adducted peptides in ECD because a larger number of product ions are charged.

\section{Experimental}

\section{Sample Preparation and Electrospray Ionization (ESI)}

Triply charged $[\mathrm{SubP}+\mathrm{H}+\mathrm{M}]^{3+}$ complexes (SubP $=$ H-RPKPQQFFGLM-NH ${ }_{2}$, Sigma, St. Louis, MO) were generated by external electrospray ionization at 80 $\mu \mathrm{L} / \mathrm{h}$ (Apollo ion source, Bruker Daltonics, Billerica, MA) of a solution containing $1 \mu \mathrm{M}$ SubP and $20 \mu \mathrm{M}$ $\mathrm{M}^{2+}\left(\mathrm{M}_{\mathrm{x}} \mathrm{Br}_{2}\right.$ for $\mathrm{M}_{\mathrm{x}}=\mathrm{Mg}, \mathrm{Fe}, \mathrm{Co}, \mathrm{Ni}, \mathrm{Cu}$, and $\mathrm{Zn}, \mathrm{M}_{\mathrm{y}} \mathrm{Cl}_{2}$ for $\mathrm{M}_{\mathrm{y}}=\mathrm{Sr}$ and $\mathrm{Ba}, \mathrm{Mn}$, and $\mathrm{CaCl}_{2} \cdot 2 \mathrm{H}_{2} \mathrm{O}$ for $\mathrm{Ca}$ ). All metal salts were purchased from Aldrich (St. Louis, $\mathrm{MO}$ ), except $\mathrm{CaCl}_{2} \cdot 2 \mathrm{H}_{2} \mathrm{O}$, which was from Fisher (Fair Lawn, NJ), at a purity higher than $99 \%$, except for $\mathrm{MgBr}_{2}$ and $\mathrm{NiBr}_{2}$, which were $98 \%$ pure. Metal salts were first dissolved in water (HPLC Grade, Fisher) to a concentration of $1-2 \times 10^{-2} \mathrm{M}$, and then diluted to $1 \times$ $10^{-4} \mathrm{M}$ before added to the spray solution (1:1 methanol/water). The ESI capillary voltage was set to $(-4)$ to $(-6) \mathrm{kV}$. Nitrogen drying gas $\left(200-250^{\circ} \mathrm{C}\right)$ was employed to assist desolvation of ESI droplets.

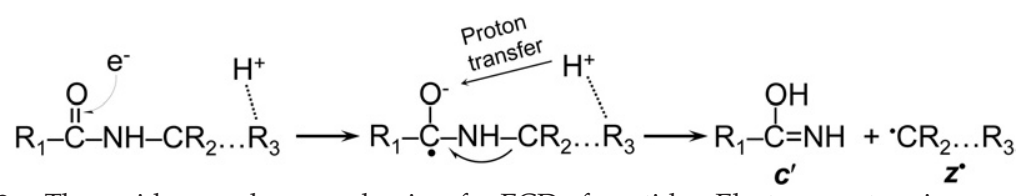

Scheme 2. The amide superbase mechanism for ECD of peptides. Electron capture in an excited state of a backbone amide group is followed by proton transfer for charge neutralization and subsequent $\mathrm{N}-\mathrm{C}_{\alpha}$ bond cleavage. 
For the formation of $[\mathrm{SubP}+2 \mathrm{H} / 3 \mathrm{H}]^{2+/ 3+}$, the solvent was 49:49:2 methanol/water/acetic acid. Acetic acid was not added for the formation of metal-protonSubP complexes because it resulted in high abundance of undesired $[\mathrm{SubP}+2 \mathrm{H}]^{2+}$ ions and very weak signal from SubP-metal complexes. Nevertheless, [SubP + $2 \mathrm{H}]^{2+}$ was always the dominant peak (6-30 times that of the species of interest) observed in the mass spectra even without addition of acetic acid. However, the use of mass-selective external ion accumulation allowed the build-up of sufficient signal for ECD of [SubP $+\mathrm{H}+$ $\mathrm{M}]^{3+}$ without over-filling the ICR cell (see below).

\section{Mass Spectrometry}

All mass spectra were collected with an actively shielded 7 tesla quadrupole-Fourier transform ion cyclotron resonance (Q-FT-ICR) mass spectrometer with a quadrupole front-end (Bruker Daltonics, Billerica, MA). Details of the operating parameters for this instrument have been reported elsewhere [51]. Briefly, ions produced by ESI were mass-selectively (5-20 Th isolation window) externally accumulated in a hexapole for $2 \mathrm{~s}$, transferred via high voltage ion optics, and captured in the ICR cell by gated trapping. This accumulation sequence was looped four to six times. In ECD experiments, further isolation was accomplished by correlated harmonic excitation fields (CHEF) [52] inside the infinity [53] ICR cell. An indirectly heated hollow dispenser cathode [54] with inner and outer diameters of 3.5 and $7.6 \mathrm{~mm}$, respectively, provided electrons for ECD $(-1 \mathrm{~V}$ bias voltage, 100-300 ms irradiation time). All data were acquired with XMASS (version 6.1, Bruker Daltonics) in broadband mode from $\mathrm{m} / \mathrm{z}=200$ to 1600 with 128 to $512 \mathrm{k}$ data points and summed over 30 to 100 scans. Experiments were repeated two or three times for error analysis.

\section{Data Analysis}

Mass spectra were analyzed with the MIDAS analysis software [55]. A Hanning window function was applied and the data were zero-filled once before magnitude calculation. Internal frequency-to-mass calibration was performed by Microsoft Excel with a two-term calibration equation [56]. The calculated masses of the precursor ion and the charge-reduced species were used for calibration. Only peak assignments with an error less than $10 \mathrm{ppm}$ were accepted. Relative inter-residue cleavage frequencies were obtained by normalizing to the total abundance of $c$ - and $z$-type ions and correcting for charge, i.e., the observed signal for a particular product ion was divided by its charge because ICR signal is proportional to charge. Absolute errors were calculated and are shown as error bars.

\section{Results and Discussion}

\section{Nomenclature}

In this report, we employ the product ion nomenclature proposed by Zubarev and coworkers [31], in which a prime ("'"') denotes addition of an $\mathrm{H}$ atom to the radical product that would result from direct homolytic cleavage of a backbone bond. Based on this nomenclature, conventional $c$ - and $z$-type ions produced by ECD are denoted as $c^{\prime}$ and $z$, respectively. We employ a similar nomenclature, $p \mathrm{M}^{+}$or $2+(\mathrm{M}=$ divalent metal; $p=a-c$ and $x-z$ ), for metal adducted product ions, as illustrated in Scheme 3. For example, $c \mathrm{M}^{2+}$ represents the complex between $\mathrm{M}^{2+}$ and a $c$-type product $-\mathrm{CHR}_{1}-\mathrm{CO}-\mathrm{NH}$. (Scheme 3), while $c^{\prime} \mathrm{M}^{2+}$ includes an additional hydrogen atom and, thus, is an even-electron species. The nomenclature for singly charged product ions produced from ECD of $\mathrm{M}^{2+}$-proton-peptide complexes is not straightforward. In our nomenclature, $\left(c^{\prime} \mathrm{M}-\mathrm{H}\right)^{+}$ denotes an even-electron species equivalent to the one that would form following proton loss from $c^{\prime} \mathrm{M}^{2+}$, thus reducing the charge by one. Similarly, $(z \mathrm{M}-\mathrm{H})^{+}$is a radical species.

\section{$E C D$ of $[S u b P+n H]^{\mathrm{n}+}(n=2$ or 3$)$}

Doubly protonated SubP has become a standard ion for optimizing ECD conditions [54, 57-60]. The relative abundance of $c^{\prime+}, z^{+}$, and $a^{++}$-type ions has been found to be reproducible in ECD of $[\mathrm{SubP}+2 \mathrm{H}]^{2+}$, although somewhat dependent on the type of instrument and ESI conditions [59]. By contrast, ECD of isolated triply protonated SubP has received very limited attention $[61,62]$. Because we are investigating the ECD behavior of metal-containing SubP trications, it was necessary to also establish the behavior of triply protonated SubP.

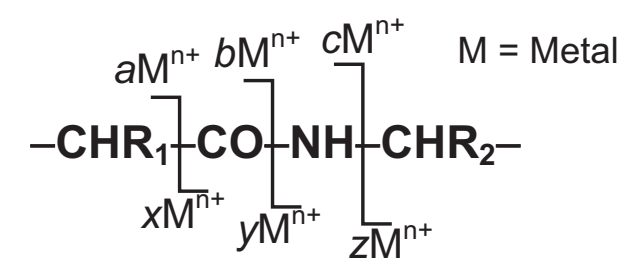

e. g.,

$$
\begin{aligned}
& c^{\cdot} \mathrm{M}^{2+}=\overbrace{}^{\mathrm{CHR}_{1}-\mathrm{CO}-\mathrm{NH}^{\circ}} \\
& \left(c^{\prime} \mathrm{M}-\mathrm{H}\right)^{+}={ }^{-\mathrm{CR}_{1}-\mathrm{C}(\mathrm{OH})=\mathrm{NH}} \\
& \left(z^{\cdot} \mathrm{M}-\mathrm{H}\right)^{+}=\frac{\dot{\mathrm{CR}}_{2}-\mathrm{CO}-\mathrm{NH}}{\mathrm{M}^{2+}}
\end{aligned}
$$

Scheme 3. Nomenclature for metal (M)-containing product ions observed following ECD of [Substance $\mathrm{P}+\mathrm{H}+\mathrm{M}]^{3+}$. 

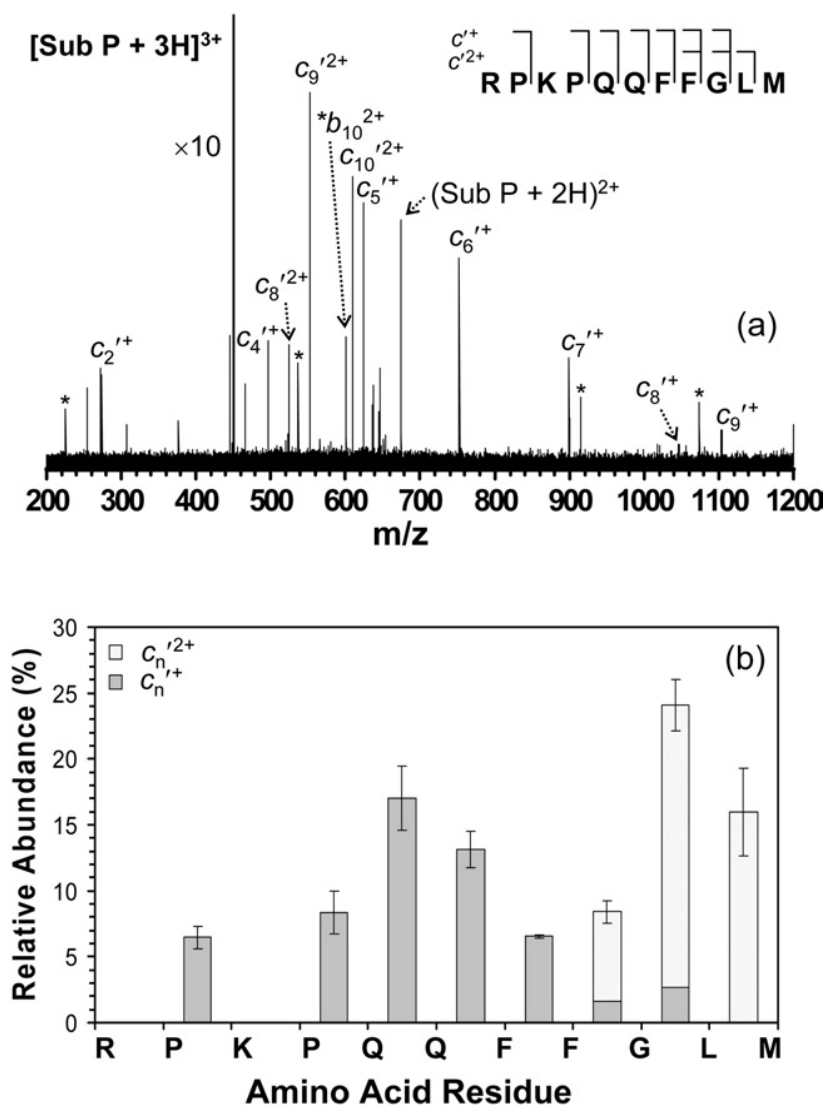

Figure 1. ECD product ion spectrum (a) (100 ms irradiation time, $-1 \mathrm{~V}$ cathode bias voltage, 50 scans) and normalized relative product ion abundances (b) from [Substance $\mathrm{P}+3 \mathrm{H}]^{3+}$. Noise peaks are labeled with asterisks (the $b_{10}{ }^{2+}$ ion was present before ECD).

Figure 1 presents the corresponding ECD mass spectrum and the observed relative abundances of product ions. Note that the displayed abundances are normalized to charge (i.e., the abundance of doubly charged ions was divided by two). As for doubly protonated SubP, singly charged $c_{4}{ }^{\prime+}-c_{9}{ }^{\prime+}$ ions are present. In addition, three doubly charged $c_{\mathrm{n}}{ }^{\prime+}$ ions are detected $(n$ $\geq 8$ ) as well as a singly charged $c_{2}{ }^{\prime+}$ ion. The protonation sites in doubly protonated SubP are generally assumed to be $\operatorname{Arg}_{1}$ and $\mathrm{Lys}_{3}$ [59, 63], consistent with the virtual absence of $z^{+}$ions following ECD of [SubP $+2 \mathrm{H}]^{2+}$ (only $z_{9}^{+}$, containing $\mathrm{Lys}_{3}$, is observed). Assuming these protonation sites are correct, the absence of $\mathrm{c}_{2}{ }^{\prime+}$ following ECD of $[\mathrm{SubP}+2 \mathrm{H}]^{2+}$ can be rationalized both within the hot hydrogen and amide superbase mechanisms (Schemes 1 and 2). For the hot hydrogen mechanism, observation of ${c_{2}}^{\prime+}$ from doubly protonated SubP would involve electron capture and neutralization at the $\mathrm{Lys}_{3}$ proton because the proton at $\operatorname{Arg}_{1}$ is required to observe $c_{2}{ }^{\prime+}$. For the amide superbase mechanism, the $\mathrm{Lys}_{3}$ proton would be the proton transferred to the $\mathrm{Pro}_{2} / \mathrm{Lys}_{3}$ amide group. Both of these scenarios should be more favorable than electron capture at/proton transfer from $\mathrm{Arg}_{1}$ because hydrogen atom transfer from a reduced guanidinium group to an amide carbonyl has been found to be endothermic [46] and the proton affinity of Arg is higher than for Lys. However, it has been proposed that the Lys side chain in doubly protonated SubP is solvated away from the N-terminus [63] due to Coulomb repulsion (consistent

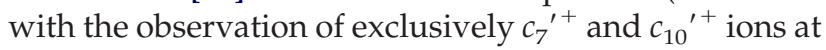
low-temperature [59], explaining why hydrogen atom/ proton transfer to form ${C_{2}}^{\prime+}$ is not observed. The additional proton in $[\mathrm{SubP}+3 \mathrm{H}]^{3+}$ must be located in the C-terminal part of the molecule and, thus, charge solvation away from the $\mathrm{N}$-terminus for the $\mathrm{Lys}_{3}$ proton is not as energetically favorable due to additional, oppositely directed, Coulomb repulsion from the extra proton. This gas-phase structure should allow more facile transfer of the $\mathrm{Lys}_{3}$ proton to the $\mathrm{Pro}_{2}$ carbonyl, resulting in formation of ${c_{2}}^{\prime+}$.

Zubarev and coworkers have suggested that the ECD fragmentation pattern from a peptide carrying $\mathrm{m}$ protons can reveal the preferred protonation sites in the corresponding $(\mathrm{m}-1)^{+}$ions [64]. For SubP, the occurrence of abundant ${c_{\mathrm{n}}}^{{ }^{2+}}(n=8-10)$ ions may suggest that the second preferred site of protonation in SubP following $\mathrm{Arg}_{1}$ is either the amide nitrogen of $\mathrm{Gly}_{9}$ (due to the structure of $c^{\prime}$ ions, the $c_{8}{ }^{2+}$ ion contains the amide nitrogen of $\mathrm{Gly}_{9}$ ) or the backbone carbonyl oxygen of $\mathrm{Phe}_{8}$ rather than the $\mathrm{Lys}_{3}$ side chain. These protonation sites should be more likely than side-chain protonation in this part of SubP because there are no basic side chains close to the C-terminus. Of these two protonation sites, the $\mathrm{Phe}_{8}$ carbonyl is more likely because backbone amide protonation has been proposed to result in amide bond cleavage to form $b$ and $y^{\prime}$ type ions [47], which are not observed. However, the complete absence of $z^{+}$ions following ECD of [SubP + $3 \mathrm{H}]^{3+}$ contradicts protonation at $\mathrm{Phe}_{8}$ being preferred over $\mathrm{Lys}_{3}$ protonation (abundant $z$-type ions are observed for metal adducted SubP, see below). On the other hand, if protons remain on $\mathrm{Arg}_{1}$ and $\mathrm{Lys}_{3}$ following ECD of $[\mathrm{SubP}+3 \mathrm{H}]^{3+}, c_{\mathrm{n}}{ }^{2+}(n=4-7)$ ions would also be expected. However, such species are probably less stable than larger $c_{\mathrm{n}}{ }^{2+}$ ions due to limited charge solvation and they should therefore be more amenable to secondary fragmentation or secondary electron capture. In the latter case, neutralization of the $\mathrm{Lys}_{3}$ proton is more likely than neutralization of the $\mathrm{Arg}_{1}$ proton for the same reasons as discussed above for doubly protonated SubP. Thus, resulting internal fragments would be neutral and can therefore not be observed to confirm this hypothesis. In any case, in the experiments discussed below, we assume the proton in $[\mathrm{SubP}+\mathrm{H}+$ $\mathrm{M}^{3+}$ is located at $\operatorname{Arg}_{1}$, the most basic site in SubP.

\section{$E C D$ of $[S u b P+H+M]^{3+}(M=M g-B a$} and $\mathrm{Mn}, \mathrm{Fe}$, and $\mathrm{Zn}$ )-Similarities

For $\mathrm{M}=\mathrm{Mg}-\mathrm{Ba}, \mathrm{Mn}, \mathrm{Fe}$, and $\mathrm{Zn}, \mathrm{ECD}$ of $[\mathrm{SubP}+\mathrm{H}+$ $\mathrm{M}]^{3+}$ resulted in protonated and/or metal adducted $c^{\prime}-$ and/or $z$-type product ions distributed across the SubP 


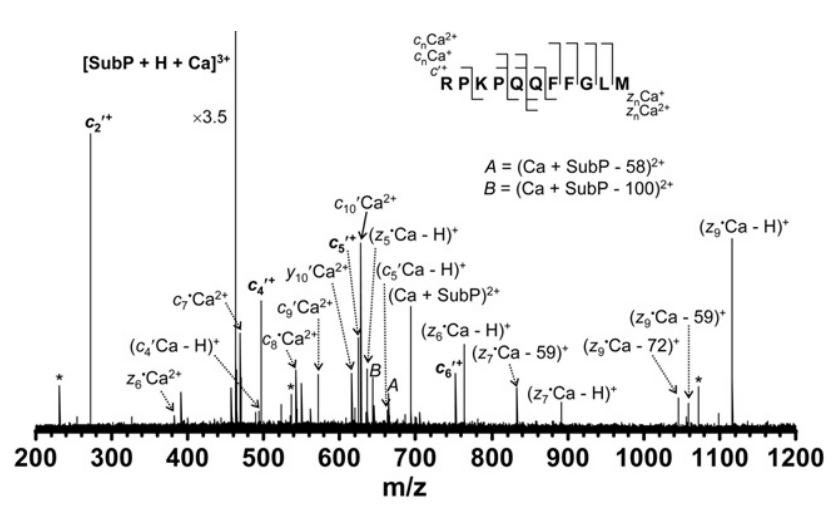

Figure 2. ECD product ion spectrum (300 ms irradiation time, $-1 \mathrm{~V}$ cathode bias voltage, 50 scans) from [Substance $\mathrm{P}+\mathrm{H}+$ $\mathrm{Ca}]^{3+}$. The major product ions are protonated $c^{\prime+}$ ions without the metal (in bold) and their complementary $(z \mathrm{Ca}-\mathrm{H})^{+}$ions, as well as $c^{\prime} \mathrm{Ca}^{2+}$ and $c \mathrm{Ca}^{2+}$ ions. Noise peaks are labeled with asterisks. Neutral losses of 58 and $100 \mathrm{amu}$ correspond to cleavages within the arginine side-chain [73].

sequence (except for the N-terminal side of Pro, which is not expected due to the cyclic structure of Pro; minor cleavage at $\mathrm{Arg}_{1}-\mathrm{Pro}_{2}$ was seen exclusively for Baadducted SubP (Figure 3d) similar to ECD of doubly and triply protonated SubP. As an example, the ECD mass spectrum of $[\mathrm{SubP}+\mathrm{H}+\mathrm{Ca}]^{3+}$ is shown in Figure 2. The normalized relative product ion abundances observed following ECD of $\mathrm{Mg}-\mathrm{Ba}, \mathrm{Mn}, \mathrm{Fe}$, and $\mathrm{Zn}$ adducted SubP are shown in Figure 3. Because of the additional proton in $[\mathrm{SubP}+\mathrm{H}+\mathrm{M}]^{3+}$ compared to previous characterization of doubly charged metal adducted species [48, 50], a larger number of $c^{\prime}$ - and $z$-type product ions is observed.

It is interesting to note that abundant protonated $c^{\prime}$ ions $\left(\mathrm{c}^{\prime+}\right)$ not containing the metal ion are observed in all cases. The mass-to-charge ratios of these (evenelectron) ions include an additional hydrogen atom as compared to direct homolytic cleavage of a backbone amine bond (similar to ECD of protonated species). In addition, they are protonated. The charge-providing proton is likely to be the original $\mathrm{Arg}_{1}$ proton, thus $\mathrm{Arg}_{1}$ cannot be the site of electron capture. An alternative explanation may be that $[\mathrm{SubP}+\mathrm{H}+\mathrm{M}]^{3+}$ is zwitterionic. Williams and coworkers have shown that the zwitterion form of glycine with a protonated N-terminus and deprotonated C-terminus is energetically favored in the gas phase upon divalent metal adduction [65]. However, because SubP is C-terminally amidated (and therefore does not contain any acidic sites), we do not believe the $[\mathrm{SubP}+\mathrm{H}+\mathrm{M}]^{3+}$ ion is zwitterionic. Similarly, alkali metal-adducted arginine methyl ester (which also lacks a C-terminal acidic site) was found to dissociate differently than alkali metal-adducted arginine upon low-energy collision activated dissociation or thermal activation. This behavior was attributed to its inability to form a zwitterion [66]. Chan and coworkers have recently proposed that divalent metal adduction to peptides can activate the acidity of amide hydrogens [48]. This claim was based on both ab initio calculations and experimental data. However, the reported calculations showed that intramolecular proton transfer from an amide to the $\mathrm{N}$-terminal amino group in the presence of a divalent metal $\left(\mathrm{Mg}^{2+}\right)$ is slightly endothermic. Also, we believe their data can be alternatively explained within the amide superbase mechanism without invoking amide deprotonation (see below).

For our results (Figures 2 and 3), a discussion on the source of the hydrogen atom may reveal mechanistic insights: for the hot hydrogen mechanism (Scheme 1), the electron would be captured at/close to the metal and somehow produce a hydrogen atom, which would be relocated to a backbone carbonyl oxygen to induce backbone cleavage. The resulting complementary $z$ ion must then contain the metal but should have lost a hydrogen atom along with one charge. For the amide superbase mechanism (Scheme 2), the electron is either captured directly at a Coulomb stabilized backbone amide group followed by proton transfer, or first captured at the metal followed by both electron and proton transfer to an amide group. Such electron-transfer, driven by the intramolecular potential difference due to the presence of protons, in metal-containing complexes has previously been proposed [36, 67]. In either case, the net mass of complementary $c^{\prime}$ and $z$ ions would be the same as in the hot hydrogen mechanism. In agreement with this discussion, the major $z$ ions observed in all cases in Figure 3 have lost one charge and one hydrogen but contain the metal $\left((z \mathrm{M}-\mathrm{H})^{+}\right.$ions $)$. Turecek and coworkers have shown that peptide coordination to metal ions greatly increases the acidity of $\mathrm{C}_{\alpha}$ protons [22, 46], thus providing a straightforward source for a superbase-type proton transfer. On the other hand, all charge reduced species, $[\mathrm{SubP}+\mathrm{M}]^{2+}$, are even-electron ions, thus undergoing facile hydrogen atom loss, supporting a hot hydrogen mechanism. Chan and coworkers observed $\mathrm{c}^{+}$ions from ECD of [peptide $+\mathrm{Mg}]^{2+}$ and concluded that such product ions can only form from doubly zwitterionic precursors [48]. We agree that their precursors are most likely zwitterions. However, due to the presence of only one acidic site (the C-terminal carboxylate group), we suggest that only one protonation/deprotonation is likely, supported by their computational data, which show that amide deprotonation is slightly endothermic (see above). Under this assumption, their [peptide $+\mathrm{Mg}]^{2+}$ system is similar to our $[\mathrm{SubP}+\mathrm{H}+\mathrm{M}]^{3+}$ systems in that there is protonation at the N-terminus, thereby explaining the charge carrier in $c^{\prime+}$ ions. The additional hydrogen can result from an amide superbase-type transfer of a $C_{\alpha}$ proton. The same authors also mention ECD experiments for $[\mathrm{SubP}+\mathrm{M}]^{2+}$ in which only metal-adducted product ions were observed, i.e., $c^{\prime+}$ ions were absent, further corroborating our claim that metal-adducted SubP is not zwitterionic.

In addition to protonated $c^{\prime}$ ions and their complementary metal-containing $(z \mathrm{M}-\mathrm{H})^{+}$ions, doubly charged $c_{\mathrm{n}}$ ions containing the metal $\left(c_{\mathrm{n}} \mathrm{M}^{2+}\right.$ or $\left.c_{\mathrm{n}}{ }^{\prime} \mathrm{M}^{2+}\right)$ are observed in all ECD spectra for $n \geq 7$. This obser- 

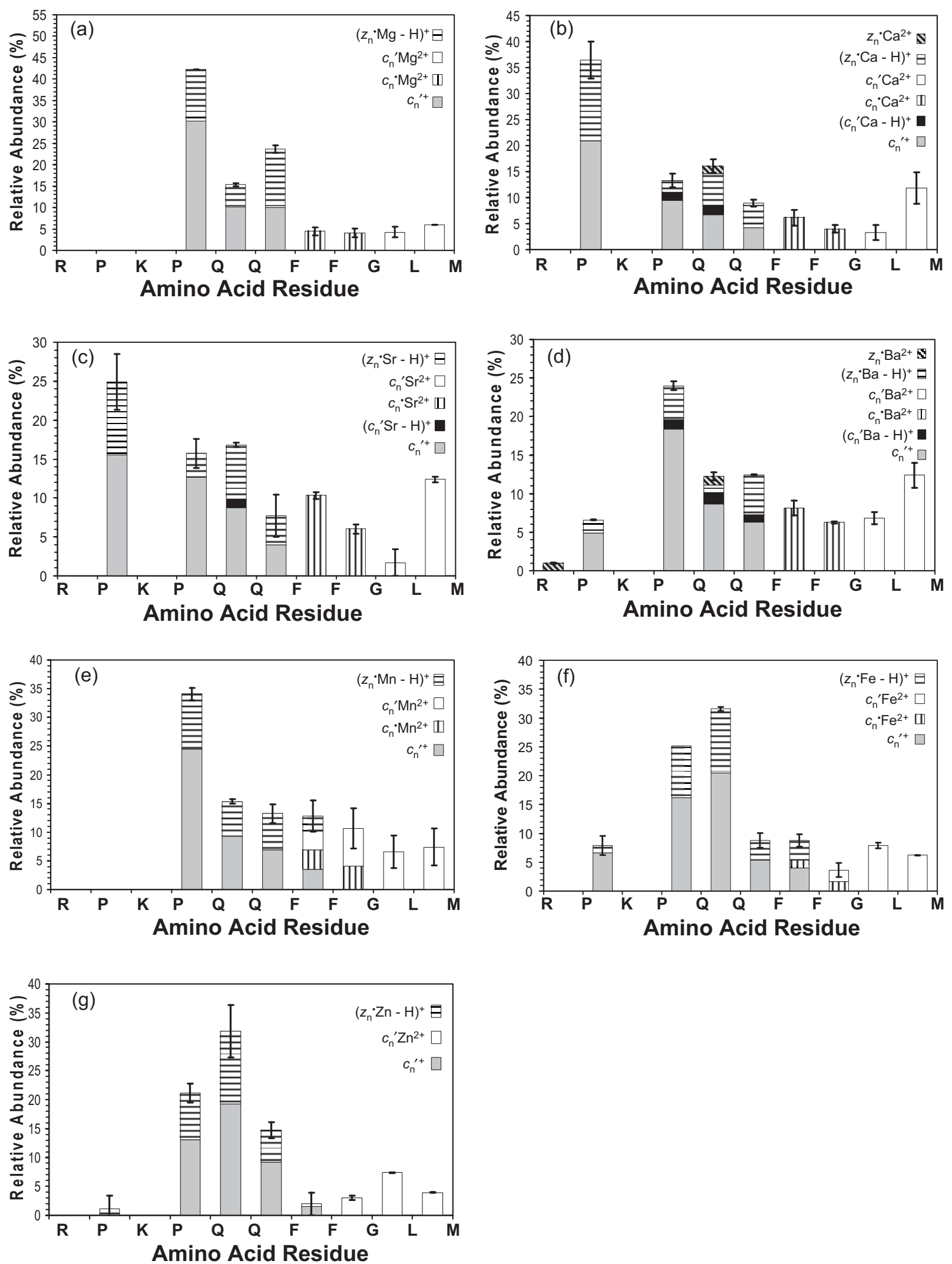

Figure 3. Relative product ion abundances observed following ECD (300 ms irradiation time, $-1 \mathrm{~V}$ cathode bias voltage, 50 or 100 scans) of [Substance $\mathrm{P}+\mathrm{H}+\mathrm{M}]^{3+}(\mathrm{M}=\mathrm{Mg}-\mathrm{Ba}, \mathrm{Mn}, \mathrm{Fe}$, and $\mathrm{Zn})$. 
vation along with the inclusion of the metal for all $z$ ions demonstrate that the metals are bound close to the C-terminus, consistent with minimization of the Coulomb energy (assuming the proton is located at $\operatorname{Arg}_{1}$ ). The metals can be coordinated by several carbonyl groups and also interact with the phenylalanine side chains of SubP (residues 7 and 8) through cation- $\pi$ interactions. In addition, $\mathrm{Zn}^{2+}$ and $\mathrm{Fe}^{2+}$, which are classified as borderline soft acids, can coordinate to amide nitrogens. Again, formation of $c_{n}{ }^{\prime} \mathrm{M}^{2+}$ can be rationalized both within the hot hydrogen and superbase mechanisms. However, the proton or hydrogen transfer has to occur within the $c$ ion. The complementary $z$ products are neutral and cannot be observed. Hydrogen migration to form $c^{-}$- and $z^{\prime}$-type products is common in ECD and may explain the occurrence of $c_{\mathrm{n}} \mathrm{M}^{2+}$ ions.

\section{$E C D$ of $[S u b P+H+M]^{3+}(M=M g-B a$ and $M n, F e$, and $\mathrm{Zn})$-Differences}

The ECD spectra obtained from SubP complexes with $\mathrm{Mg}-\mathrm{Ba}, \mathrm{Mn}, \mathrm{Fe}$, and $\mathrm{Zn}$ also display some differences depending on the type of metal. First, singly charged $\left(c_{\mathrm{n}}{ }^{\prime} \mathrm{M}-\mathrm{H}^{+}\right)$ions are observed for Ca $(n=4,5)$, Sr $(n=5)$, and Ba $(n=4-6)$ (Figure $3 b-d)$. Such ions can be formed via secondary electron capture by $c_{n} \mathrm{M}^{2+}$ ions followed by proton or hydrogen transfer. We believe this behavior is best rationalized within a superbase-type mechanism (i.e., proton transfer) because it easily explains the sources of the two hydrogens (two different $C_{\alpha}$ protons: one for each cleavage event, as described below). The second electron could possibly be captured at $\operatorname{Arg}_{1}$ (assuming the first electron was captured at the metal and/or amide group), however, that proton is not likely to be solvated onto the $c_{\mathrm{n}}{ }^{\prime} \mathrm{M}^{2+}$ ion due to Coulomb repulsion and such an event is therefore not likely to cause backbone cleavage. Kleinnijenhuis et al. [50] have proposed that the divalent metal in doubly charged metal-oxytocin complexes serves as the initial electron capture site followed by transfer to other locations to form a hydrogen radical. We argue that those other locations may be backbone amide groups, such as in the amide superbase mechanism. Thus, hydrogen radicals do not need to be formed. A secondary electron capture can then logistically cause cleavage between a different pair of amino acid residues by being transferred to a different amide group followed by proton transfer. Interestingly, the second ionization energy (IE2) for $\mathrm{Ca}, \mathrm{Sr}$, and $\mathrm{Ba}$ is lower $(10.0-11.9 \mathrm{eV})$ than for the other metals characterized (15.0-20.3 eV), see Table 1 . We reason that the IE2 value may indicate how facile electron-transfer from the metal, e.g., to a peptide amide group, is following the initial electron capture event. That is, lower IE2 values may correspond to more facile electron-transfer and thereby increase the probability for secondary fragmentation to form $\left(c_{\mathrm{n}}{ }^{\prime} \mathrm{M}-\mathrm{H}^{+}\right)$ions. Further support for this hypothesis is provided by the observation of $z_{6} \mathrm{M}^{2+}$ ions following ECD of $\mathrm{Ca}$ and $\mathrm{Ba}$ adducted SubP. Because these product ions appear to contain a divalent metal, the electron must have been transferred to sites rather remote from the metal (assuming the metal is located close to the C-terminus as discussed above).

A second noticeable difference between the spectra obtained following ECD of $[\mathrm{SubP}+\mathrm{H}+\mathrm{M}]^{3+}(\mathrm{M}=$ $\mathrm{Mg}-\mathrm{Ba}, \mathrm{Mn}, \mathrm{Fe}$, and $\mathrm{Zn}$ ) is the relative abundance of the various product ions, particularly the large variation in the magnitude of the ${C_{2}}^{\prime+}$ ion. Relating to the discussion above for doubly and triply protonated SubP and previous literature discussions [59, 64, 68, 69], these differences may reveal differences in the gas-phase structures of these peptide-metal ion complexes. As for exclusively protonated SubP, proton or hydrogen transfer to $c_{2}$ is required for its observation. In either case, a proton or hydrogen atom must be located proximal to the $\mathrm{N}$-terminus and, for the amide superbase mechanism, the electron has to be captured by/transferred to the $\mathrm{Pro}_{2} / \mathrm{Lys}_{3}$ amide group. Again, $\mathrm{Ca}, \mathrm{Sr}$, and $\mathrm{Ba}$ adduction, this time joined by Fe (Figure $3 \mathrm{f}$ ), displays a unique behavior: ${c_{2}}^{\prime+}$ is rather abundant. In fact, for $\mathrm{Ca}$ and $\mathrm{Sr}, \mathrm{C}_{2}{ }^{+}$is the most abundant product ion along

Table 1. Ionic radii and IE2 ${ }^{\mathrm{a}}$ values for alkali-earth and first-row transition metal cations ${ }^{\mathrm{b}}$

Ionic Radii ( $\AA$ )

\begin{tabular}{|c|c|c|c|c|c|}
\hline $\mathrm{M}^{2+}$ & Pauling & 4-Coordinate & 6-Coordinate & 8-Ccoordinate & IE2 (eV) \\
\hline $\mathrm{Mg}^{2+}$ & 0.65 & 0.71 & 0.86 & 1.03 & 15.0 \\
\hline $\mathrm{Ca}^{2+}$ & 0.99 & I & 1.14 & 1.26 & 11.9 \\
\hline $\mathrm{Sr}^{2+}$ & 1.13 & I & 1.32 & 1.40 & 11.0 \\
\hline $\mathrm{Ba}^{2+}$ & 1.35 & I & 1.49 & 1.56 & 10.0 \\
\hline $\mathrm{Mn}^{2+}$ & I & 0.80 & $0.81 / 0.97^{c}$ & 1.10 & 15.6 \\
\hline $\mathrm{Fe}^{2+}$ & I & 0.77 & $0.75 / 0.92^{c}$ & 1.06 & 16.2 \\
\hline $\mathrm{Co}^{2+}$ & I & 0.72 & $0.75 / 0.88^{c}$ & 1.04 & 17.1 \\
\hline $\mathrm{Ni}^{2+}$ & l & 0.69 & 0.83 & l & 18.2 \\
\hline $\mathrm{Cu}^{2+}$ & I & 0.71 & 0.87 & I & 20.3 \\
\hline $\mathrm{Zn}^{2+}$ & 0.74 & 0.74 & 0.88 & 1.04 & 18.0 \\
\hline
\end{tabular}

a|E2 = second ionization energy.

${ }^{b}$ Values are taken from http://www.webelements.com.

'Denotes ionic radii for low/high spin electronic configurations. 
with the complementary $\left(z_{9}^{\prime} \mathrm{M}-\mathrm{H}\right)^{+}$ion. As above, we believe this behavior favors a superbase-type mechanism because it seems to be correlated with the lower IE2 of these metals, which may favor electron-transfer to amides remote from the metal. Such amides may display more favorable Coulomb stabilization due to the proximal $\mathrm{Arg}_{1}$ proton. However, IE2 for Fe is rather high $(16.2 \mathrm{eV})$, suggesting that conformational effects are also involved. The relatively high magnitude of ${c_{2}}{ }^{+}$ for Fe-adducted SubP may be related to the small size of Fe (see Table 1), favoring a more compact (i.e., more folded) structure that facilitates proton transfer to the $\mathrm{PrO}_{2} / \mathrm{Lys}_{3}$ amide group. Similar reasoning can also explain the lower magnitude of ${c_{2}}^{\prime+}$ following ECD of Ba-adducted SubP (Ba has the lowest IE2 of all the metals studied): the large size of Ba may prevent formation of a gas phase folded structure for that complex due to a more extended Coulomb field. An alternative explanation for the Fe-containing complex could be the softer acid nature of $\mathrm{Fe}^{2+}$ (see above), thereby allowing coordination to the $\mathrm{Lys}_{3}$ side chain.
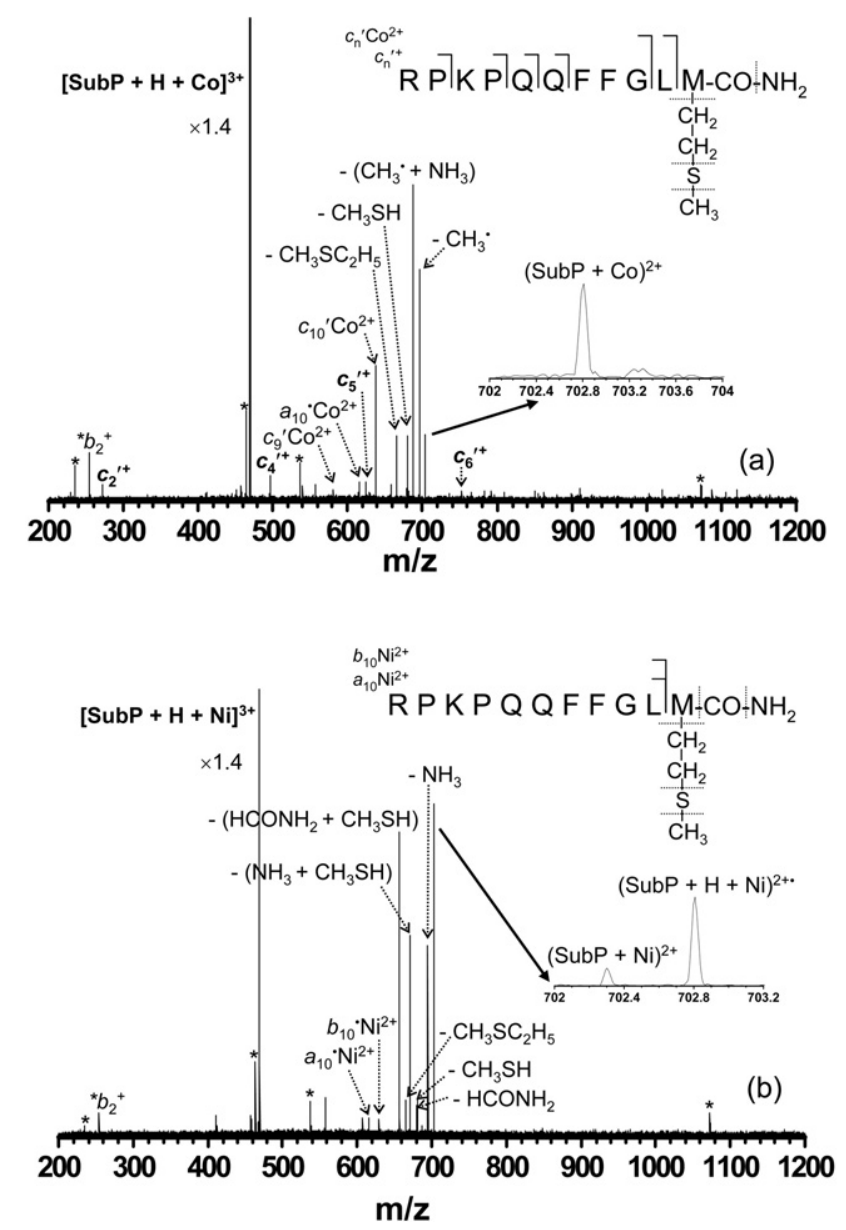

Figure 4. ECD product ion spectra (300 ms irradiation time, -1 $\mathrm{V}$ cathode bias voltage) from [Substance $\mathrm{P}+\mathrm{H}+\mathrm{Co}]^{3+}$ (a) $(100$ scans) and $[\text { Substance } \mathrm{P}+\mathrm{H}+\mathrm{Ni}]^{3+}$ (b) (100 scans). The major product ions correspond to cleavage within the C-terminal methionine side-chain. The insets show expanded views of the charged reduced species. Noise peaks are labeled with asterisks.
$E C D$ of $[\mathrm{SubP}+\mathrm{H}+\mathrm{M}]^{3+}(\mathrm{M}=\mathrm{Co}-\mathrm{Cu})$

$\mathrm{ECD}$ of $[\mathrm{SubP}+\mathrm{H}+\mathrm{Co}]^{3+}$ and $[\mathrm{SubP}+\mathrm{H}+\mathrm{Ni}]^{3+}$ is illustrated in Figure 4. The product ions following ECD of these two SubP-metal ion complexes are significantly different from the $\mathrm{Mg}-\mathrm{Ba}, \mathrm{Mn}, \mathrm{Fe}$, and $\mathrm{Zn}$ complexes discussed above. For Co (Figure 4a), four ${c_{\mathrm{n}}}^{{ }^{+}}$ions along with two $c_{\mathrm{n}}{ }^{\prime} \mathrm{Co}^{2+}$ ions are observed. However, no $z$-type ions are detected. The dominant products correspond to neutral losses from the C-terminal methionine side chain, as indicated in the inset. In addition, the relative abundances of $c^{\prime}$-type ions are significantly different compared to $\mathrm{Mg}-\mathrm{Ba}, \mathrm{Mn}, \mathrm{Fe}$, and $\mathrm{Zn}$ with the $c_{10}{ }^{\prime} \mathrm{Co}^{2+}$ ion, corresponding to cleavage $\mathrm{N}$-terminal to methionine, being the most abundant. Also, an $a_{10} \mathrm{Co}^{2+}$ ion, corresponding to cleavage at the same interresidue position, is observed. Because $\mathrm{Co}^{2+}$ is a borderline soft acid, the metal can coordinate to nitrogen atoms. The Irving-Williams series predicts that it is more likely to do so than $\mathrm{Fe}^{2+}$ [2] (discussed above). Consequently, it should also have a higher propensity for binding to sulfur (a softer ligand than nitrogen [2] and, thus, it is likely coordinated to the C-terminal Met side chain, consistent with the Coulomb repulsion from the $\mathrm{N}$ terminal protonated Arg. IE2 for Co is significantly higher $(17.1 \mathrm{eV})$ than for the metals discussed above (with the exception of $\mathrm{Zn}$ ). Thus, electron-transfer from the metal may be less favorable, consistent with the clustering of the preferred cleavage positions around Met. The ECD behavior of Ni-adducted SubP (Figure $4 b)$ supports this hypothesis. Here, exclusively cleavage in the close vicinity of Met is observed, consistent with both the even higher IE2 $(18.2 \mathrm{eV})$ and its higher propensity to bind nitrogen/sulfur [2]. The ECD behavior of Zn-adducted SubP suggests that the metal binding mode is more important than IE2 for $\mathrm{Co}^{2+}$ and $\mathrm{Ni}^{2+}$ as the zinc complex did not display sequestered cleavage. No $c^{\prime}$ or $z$-type ions were detected from the Ni-SubP complex. Another unique feature of the $\mathrm{Ni}$ ECD spectrum is that the charge reduced species is mainly a radical (see inset).

Again, we believe the behavior of $\mathrm{Co}^{-}$and $\mathrm{Ni}$ adducted SubP can be best rationalized within a superbase type mechanism. The hot hydrogen mechanism involves electron capture either at the Arg proton or the metal followed by hydrogen transfer. This hydrogen atom should not be influenced by the IE2 of metals and the only straightforward explanation for the drastically different behavior observed for $\mathrm{Co}$ and Ni-adducted SubP is a considerably different gas-phase conformation. $\mathrm{Co}$ and $\mathrm{Ni}$ have rather small ionic radii (see Table 1). Thus, their internal solvation may not extend as far towards the SubP N-terminus as for the other metal ions. However, in a superbase-type mechanism, the transfer of electrons to backbone amide groups can easily be envisioned to be influenced by the IE2 of metals. Higher values may not allow transfer to sites more remote from the metal, resulting in the sequestered cleavages observed for $\mathrm{Co}$ and Ni. This hypothe- 
sis is supported by the observation that $\mathrm{Ni}$ (with the highest IE2) forms a more stable charge-reduced radical that undergoes only minimum hydrogen atom loss.

As observed in the previous characterization of doubly charged $\mathrm{Cu}$-oxytocin complexes [50], we found the behavior of $\mathrm{Cu}$-adducted triply charged SubP to be drastically different from all other metal ion complexes. Similar to the previous studies, the main product ions following ECD of $[\mathrm{SubP}+\mathrm{H}+\mathrm{Cu}]^{3+}$ (see Figure 5) are even-electron $b$-type product ions, as in vibrational excitation. However, the major product ion corresponds to neutral loss of ammonia. Kleinnijenhuis et al. [50] have suggested that because $\mathrm{Cu}$ has a $(+1)$ oxidation state with a closed d shell, the ECD electron can be captured at the metal and reduce it to $\mathrm{Cu}(\mathrm{I})$ rather than participating in radical-mediated fragmentation processes. This reduction results in a vibrationally exited $\mathrm{Cu}(\mathrm{I})$-peptide species that can dissociate into the typical $b$ and $y^{\prime}$-type product ions observed. We agree this mechanism seems plausible and it also correlates with the high IE2 of $\mathrm{Cu}(20.3 \mathrm{eV}$, see Table 1). However, preliminary experiments from our group [70] show that reduction to $\mathrm{Cu}(\mathrm{I})$ can also occur during ESI (as also observed by others [71]) and we hypothesize that internal electron-transfer may occur within $\mathrm{Cu}$-adducted gas-phase peptides, depending on their amino acid composition, thus resulting in a precursor ion with a radical site. Electron capture by this species may produce a vibrationally excited even-electron peptide that dissociates into the observed $b$ and $y^{\prime}$-type product ions. This behavior will be discussed in detail in a separate publication. An alternative explanation for the unique behavior of copper-adducted peptides can once again be related to its binding mode: $\mathrm{Cu}^{2+}$ has the highest propensity of all the metals investigated to bind to nitrogen rather than oxygen atoms [2]. Recently, Bowers and coworkers found that copper-adducted oxytocin displays unique MS and MS/MS behavior as compared to, e.g., $\mathrm{Zn}$ adduction [72]. These authors proposed that nitrogen binding (as opposed to oxygen binding) of $\mathrm{Cu}^{2+}$ results in an oxytocin structure incom-

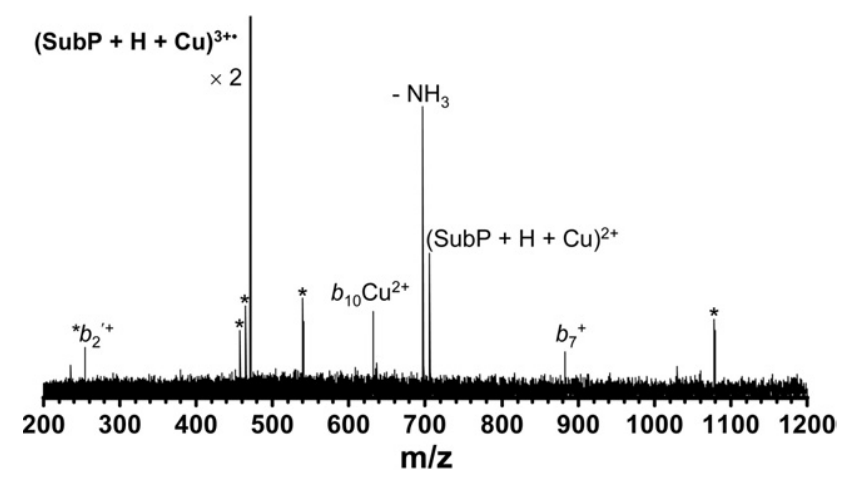

Figure 5. ECD product ion spectrum ( $300 \mathrm{~ms}$ irradiation time, $-1 \mathrm{~V}$ cathode bias voltage) from [Substance $\mathrm{P}+\mathrm{H}+\mathrm{Cu}]^{3+}(50$ scans). No $c$ - or z-type ions are observed. However, $b$-type cleavages, characteristic of slow heating dissociation of peptides, are detected. patible with receptor binding, further supported by DFT calculations.

\section{Conclusions}

ECD of doubly and triply protonated SubP reveals that $\mathrm{Arg}_{1}$ and $\mathrm{Lys}_{3}$ are likely the preferred protonation sites in SubP. The main gas-phase structural difference between the two charge states appears to be the solvation of the $\mathrm{Lys}_{3}$ proton as evidenced by an abundant ${C_{2}}^{\prime+}$ ion from ECD of $[\mathrm{SubP}+3 \mathrm{H}]^{3+}$. This fragment is absent following ECD of $[\mathrm{SubP}+2 \mathrm{H}]^{2+}$, supporting solvation of the $\mathrm{Lys}_{3}$ proton away from the $\mathrm{N}$-terminus for the $2^{+}$ charge state. ECD of $[\mathrm{SubP}+\mathrm{H}+\mathrm{M}]^{3+}(\mathrm{M}=\mathrm{Mg}-\mathrm{Ba}$ and $\mathrm{Mn}-\mathrm{Zn}$ ) exhibits very different behavior depending on the type of metal ion. For SubP complexes with $\mathrm{Mg}-\mathrm{Ba}, \mathrm{Mn}, \mathrm{Fe}$, and $\mathrm{Zn}$, which have I2 values in the range 10.0 to 16.2 (except for $\mathrm{Zn}$, which has an IE2 of 18.0), ECD mainly results in protonated $c^{+}$ions (not observable from [SubP $+\mathrm{M}]^{2+}$ complexes) and their complementary $(z \mathrm{M}-\mathrm{H})^{+}$ions, as well as $c^{\prime} \mathrm{M}^{2+}$ and $c \mathrm{M}^{2+}$ ions. This behavior can be rationalized both within a hot hydrogen mechanism $[29,36,41]$ (Scheme 1) and an amide superbase mechanism [46] (Scheme 2) with initial electron capture occurring at the metal although the source of the hydrogen atom for the former mechanism is unclear. However, the formation of $\left(c_{n}{ }^{\prime} \mathrm{M}-\mathrm{H}\right)^{+}$ions for Ca-Ba complexes, which implies secondary electron capture, favors a superbase-type mechanism, as does the observation of $z_{6} \mathrm{M}^{2+}$ ions for $\mathrm{Ca}$ and $\mathrm{Ba}$ complexes. In addition, the observed correlation between ECD behavior and metal IE2 further supports a superbase mechanism because hydrogen atom transfer (such as in the hot hydrogen mechanism) should not be affected by that value. However, other factors, including structural effects and metal ion binding mode, seem to be involved in the ECD behavior of $[\mathrm{SubP}+\mathrm{H}+\mathrm{M}]^{3+}$ ions and it cannot be excluded that several mechanisms are in operation and that the major mechanism may vary depending on the type of metal ion. The insights presented in this manuscript suggest that ECD behavior can be directed depending on the choice of divalent metal ion. This observation has interesting implications for targeted gas-phase analysis of modified peptides.

\section{Acknowledgments}

This work was supported by the Searle Scholars Program and the University of Michigan.

\section{References}

1. Whitfield, D. M.; Stojkovski, S.; Sarkar, B. Metal Coordination to Carbohydrates-Structures and Function. Coord. Chem. Rev. 1993, 122, 171-225.

2. Lippard, S. J.; Berg, J. M. Principles of Bioinorganic Chemistry; University Science Books: Mill Valley, CA, 1994, p 411.

3. Freiser, B. S., Ed. Organometallic Ion Chemistry; Kluwer Academic Publishers: Dordrecht, The Netherlands, 1996, p 352.

4. Sigel, A.; Sigel, H., Eds. Interactions of Metal Ions with Nucleotides, Nucleic Acids, and their Constituents; Dekker: New York, NY, 1996, p 561. 
5. Crivici, A.; Ikura, M. Molecular and Structural Basis of Target Recognition by Calmodulin. Annu. Rev. Biophys. Biomol. Struct. 1995, 24 , 85-116.

6. Frausto-da Silva, J. J. R.; Williams, R. J. P. The Biological Chemistry of the Elements; Clarendon Press: Oxford, UK, 1991, p 814.

7. Holm, R. H.; Kennepohl, P.; Solomon, E. I. Structural and Functional Aspects of Metal Sites in Biology. Chem. Rev. 1996, 96, 2239-2314.

8. Case, M. A.; McLendon, G. L. Metal-Assembled Modular Proteins: Toward Functional Protein Design. Acc. Chem. Res. 2004, 37, 754-762.

9. Licinci, G.; Scrimin, P. Metal-Ion Binding Peptides: From Catalysis to Protein Targeting. Angew. Chem. Int. Ed. 2003, 42, 4572-4575.

10. Gatlin, C. L.; Turecek, F.; Vaisar, T. Copper(II) Amino Acid Complexes in the Gas Phase. J. Am. Chem. Soc. 1995, 117, 3637-3638.

11. Cerda, B.; Cornett, L.; Wesdemiotis, C. Probing the Interaction of Alkali and Transition Metal Ions with Bradykinin and Its Des-Arginine Derivatives via Matrix-Assisted Laser Desorption/Ionization and Postsource Decay Mass Spectrometry. Int. J. Mass Spectrom. 1999, 193, 205-226.

12. Hu, P. F.; Loo, J. A. Gas-Phase Coordination Properties of $\mathrm{Zn} 2+, \mathrm{Cu} 2+$ $\mathrm{Ni} 2+$, and $\mathrm{Co} 2+$ with Histidine-Containing Peptides. J. Am. Chem. Soc 1995, 117, 11314-11319.

13. Kohtani, M.; Jarrold, M. F.; Wee, S.; O'Hair, R. A. J. Metal Ion Interactions with Polyalanine Peptides. J. Phys. Chem. B 2004, 108, 6093-6097.

14. Nemirovskiy, O. V.; Gross, M. L. Determination of Calcium Binding Sites in Gas-Phase Small Peptides by Tandem Mass Spectrometry. I. Am . Soc. Mass Spectrom. 1998, 9, 1020-1028.

15. Nemirovskiy, O. V.; Gross, M. L. Gas-Phase Studies of the Interactions of Fe2+ with Cysteine-Containing Peptides. J. Am. Soc. Mass Spectrom. $1998,9,1285-1292$.

16. Nemirovskiy, O. V.; Gross, M. L. Intrinsic Ca2+ Affinities of Peptides: Application of the Kinetic Method to Analogs of Calcium-Binding Site III of Rabbit Skeletal Troponin C. J. Am. Soc. Mass Spectrom. 2000, 11, $770-779$.

17. Newton, K. A.; McLuckey, S. A. Gas-Phase Peptide/Protein Cationizing Agent Switching via Ion/Ion Reactions. J. Am. Chem. Soc. 2003, 125, 12404-12405

18. Payne, A. H.; Glish, G. L. Gas-Phase Ion/Ion Interactions between Peptides or Proteins and Iron Ions in a Quadrupole Ion Trap. Int. J. Mass Spectrom. 2001, 204, 47-54.

19. Reiter, A.; Adams, J.; Zhao, H. Intrinsic (Gas-Phase) Binding of Co2+ and Ni2 + by Peptides-A Direct Reflection of Aqueous-Phase Chemistry. J. Am. Chem. Soc. 1994, 116, 7827-7838.

20. Taraszka, J. A.; Li, J. W. Clemmer, D. E. Metal-Mediated Peptide Ion Conformations in the Gas Phase. J. Phys. Chem. B 2000, 104, 4545-4551

21. Teesch, L.; Adams, J. Intrinsic Interactions Between Alkaline-Earth Metal Ions and Peptides-A Gas-Phase Study. J. Am. Chem. Soc. 1990, $112,4110-4120$

22. Vaisar, T.; Gatlin, C. L.; Turecek, F. Metal-Ligand Redox Reactions in Gas-Phase Quaternary Peptide-Metal Complexes by Electrospray Ionization Mass Spectrometry. Int. J. Mass Spectrom. 1997, 162, 77-87.

23. Loo, J. A. Probing Protein-Metal Ion Interactions by Electrospray Ionization Mass Spectrometry: Enolase and Nucleocapsid Protein. Int. J. Mass Spectrom. 2001, 204, 113-123.

24. Nemirovskiy, O. V.; Gross, M. L. Electrospray Ionization Mass Spectrometry and Hydrogen/Deuterium Exchange for Probing the Interaction of Calmodulin with Calcium. I. Am. Soc. Mass Spectrom. 1999, 10, $711-718$.

25. Nemirovskiy, O. V.; Ramanathan, R.; Gross, M. L. Investigation of Calcium-Induced, Noncovalent Association of Calmodulin with Melittin by Electrospray Ionization Mass Spectrometry. I. Am. Soc. Mass Spectrom. 1997, 8, 809-812.

26. Zubarev, R. A.; Kelleher, N. L.; McLafferty, F. W. Electron Capture Dissociation of Multiply Charged Protein Cations. A Nonergodic Process. J. Am. Chem. Soc. 1998, 120, 3265-3266.

27. Cooper, H. J.; Håkansson, K.; Marshall, A. G. The Role of Electron Capture Dissociation in Biomolecular Analysis. Mass Spectrom. Rev. 2005, 24, 201-222.

28. Meng, F.; Forbes, A. J.; Miller, L. M.; Kelleher, N. L. Detection and Localization of Protein Modifications by High Resolution Tandem Mass Spectrometry. Mass Spectrom. Rev. 2005, 24, 57-77.

29. Zubarev, R. A. Reactions of Polypeptide Ions with Electrons in the Gas Phase. Mass Spectrom. Rev. 2003, 22, 57-77.

30. Zubarev, R. A. Electron Capture Dissociation Tandem Mass Spectrometry. Curr. Opin. Biotechnol. 2004, 15, 12-16.

31. Kjeldsen, F.; Haselmann, K.; Budnik, B. A.; Jensen, F.; Zubarev, R. A Dissociative Capture of Hot Electrons by Polypeptide Polycations: An Efficient Process Accompanied by Secondary Fragmentation. Chem. Phys. Lett. 2002, 356, 201-206.

32. Roepstorff, P.; Fohlman, J. Proposal for a Common Nomenclature for Sequence Ions in Mass Spectra of Peptides. Biomed. Mass Spectrom. 1984, 11, 601-601

33. Ge, Y.; Lawhorn, B. G.; El-Naggar, M.; Strauss, E.; Park, J. H.; Begley, T. P.; McLafferty, F. W. Top-Down Characterization of Larger Proteins (45 kDa) by Electron Capture Dissociation Mass Spectrometry. J. Am. Chem. Soc. 2002, 124, 672-678.

34. Sze, S. K.; Ge, Y.; Oh, H.; McLafferty, F. W. Top-Down Mass Spectrometry of a 29-kDa Protein for Characterization of any Posttranslational Modification Within One Residue. Proc. Natl. Acad. Sci. U.S.A. 2002, 99 1774-1779.
35. Turecek, F. N-C- $\alpha$ Bond Dissociation Energies and Kinetics in Amide and Peptide Radicals. Is the Dissociation a Nonergodic Process? J. Am. Chem. Soc. 2003, 125, 5954-5963.

36. Zubarev, R. A.; Haselmann, K. F.; Budnik, B.; Kjeldsen, F.; Jensen, F. Towards an Understanding of the Mechanism of Electron Capture Dissociation: A Historical Perspective and Modern Ideas. Eur. Mass Spectrom. 2002, 8, 337-349.

37. Zubarev, R. A.; Horn, D. M.; Fridriksson, E. K.; Kelleher, N. L.; Kruger, N. A.; Lewis, M. A.; Carpenter, B. K.; McLafferty, F. W. Electron Capture Dissociation for Structural Characterization of Multiply Charged Protein Cations. Anal. Chem. 2000, 72, 563-573.

38. Syrstad, E. A.; Stephens, D. D.; Turecek, F. Hydrogen Atom Adducts to the Amide Bond. Generation and Energetics of Amide Radicals in the Gas Phase. J. Phys. Chem. A 2003, 107, 115-126.

39. Turecek, F.; Syrstad, E. A. Mechanism and Energetics of Intramolecular Hydrogen Transfer in Amide and Peptide Radicals and Cation Radicals. J. Am. Chem. Soc. 2003, 125, 3353-3369.

40. Turecek, F.; Syrstad, E. A.; Seymour, J. L.; Chen, X.; Yao, C. Peptide Cation Radicals. A Computational Study of the Competition between Peptide N-C Alpha Bond Cleavage and Loss of the Side Chain in the [GlyPhe $-\mathrm{NH} 2+\mathrm{H}]$ (+center dot) Cation Radical. J. Mass Spectrom. 2003, 38, 1093-1104.

41. Zubarev, R. A.; Kruger, N. A.; Fridriksson, E. K.; Lewis, M. A.; Horn, D. M.; Carpenter, B. K.; McLafferty, F. W. Electron Capture Dissociation of Gaseous Multiply-Charged Proteins is Favored at Disulfide Bonds and Other Sites of High Hydrogen Atom Affinity. J. Am. Chem. Soc. 1999, 121, 2857-2862.

42. Breuker, K.; Oh, H. B.; Lin, C.; Carpenter, B. K.; McLafferty, F. W. Nonergodic and Conformational Control of the Electron Capture Dissociation of Protein Cations. Proc. Natl. Acad. Sci. U.S.A. 2004, 101, 14011-14016.

43. Iavarone, A. T.; Paech, K.; Williams, E. R. Effects of Charge State and Cationizing Agent on the Electron Capture Dissociation of a Peptide. Anal. Chem. 2004, 76, 2231-2238.

44. Leymarie, N.; Costello, C. E.; O'Connor, P. B. Electron Capture Dissociation Initiates a Free Radical Reaction Cascade. J. Am. Chem. Soc. 2003, 125, 8949-8958.

45. Sobczyk, M.; Anusiewicz, W.; Berdys-Kochanska, J.; Sawicka, A.; Skurski, P.; Simons, J. Coulomb-Assisted Dissociative Electron Attachment: Application to a Model Peptide. J. Phys. Chem. A 2005, 109, 250-258.

46. Syrstad, E. A.; Turecek, F. Toward a General Mechanism of Electron Capture Dissociation. J. Am. Soc. Mass Spectrom. 2005, 16, 208-224.

47. Uggerud, E. Electron Capture Dissociation of the Disulfide Bond-a Quantum Chemical Model Study. Int. J. Mass Spectrom. 2004, 234, 45-50.

48. Fung, Y. M. E.; Liu, H.; Chan, T. W. D. Electron Capture Dissociation of Peptides Metalated with Alkaline-Earth Metal Ions. J. Am. Soc. Mass Spectrom. 2006, 17, 757-771.

49. Kellersberger, K. A.; Fabris, D. Top-Down Investigation of Metal Coordination in Metalloproteins by ESI-FTMS and Electron Capture Dissociation. Proceedings of the 52nd ASMS Conference on Mass Spectrometry and Allied Topics; Nashville, TN, May, 2004; CD-ROM.

50. Kleinnijenhuis, A. J Mihalca, R Heeren, R. M. A Heck, A. J. R Atypical Behavior in the Electron Capture Induced Dissociation of Biologically Relevant Transition Metal Ion Complexes of the Peptide Hormone Oxytocin. Int. J. Mass Spectrom. 2006, in press.

51. Yang, J · Mo, J · Adamson, J. T. Håkansson, K Characterization of Oligodeoxynucleotides by Electron Detachment Dissociation Fourier Transform Ion Cyclotron Resonance Mass Spectrometry. Anal. Chem. 2005, 77, 1876-1882.

52. de Koning, L. J.; Nibbering, N. M. M.; van Orden, S. L.; Laukien, F. H. Mass Selection of Ions in a Fourier Transform Ion Cyclotron Resonance Trap using Correlated Harmonic Excitation Fields (CHEF). Int. J. Mass Spectrom. 1997, 165, 209-219.

53. Caravatti, P.; Allemann, M. The Infinity Cell-A New Trapped Ion Cell with Radiofrequency Covered Trapping Electrodes for Fourier Transform Ion Cyclotron Resonance Mass Spectrometry. Org. Mass Spectrom. 1991, 26, 514-518.

54. Tsybin, Y. O.; Witt, M.; Baykut, G.; Kjeldsen, F.; Håkansson, P. Combined Infrared Multiphoton Dissociation and Electron Capture Dissociation with a Hollow Electron Beam in Fourier Transform Ion Cyclotron Resonance Mass Spectrometry. Rapid Commun. Mass Spectrom. 2003, 17, 1759-1768.

55. Senko, M. W.; Canterbury, J. D.; Guan, S.; Marshall, A. G. A HighPerformance Modular Data System for FT-ICR Mass Spectrometry. Rapid Commun. Mass Spectrom. 1996, 10, 1839-1844.

56. Ledford, E. B.; Jr.; Rempel, D. L.; Gross, M. L. Space Charge Effects in Fourier Transform Mass Spectrometry Mass Calibration. Anal. Chem. 1984, 56, 2744-2748.

57. Axelsson, J: Palmblad, M. Håkansson, K: Håkansson, P. Electron Capture Dissociation of Substance P Using a Commercially Available Fourier Transform Ion Cyclotron Resonance Mass Spectrometer. Rapid Commun. Mass Spectrom. 1999, 13, 474-477.

58. Håkansson, K. Emmett, M. R. Hendrickson, C. L.; Marshall, A. G. High Sensitivity Electron Capture Dissociation Tandem FT-ICR Mass Spectrometry of Microelectrosprayed Peptides. Anal. Chem. 2001, 73, 36053610.

59. Mihalca, R. Kleinnijenhuis, A. J.; McDonnell, L. A.; Heck, A. J. R. Heeren, R. M. A. Electron Capture Dissociation at Low Temperatures Reveals Selective Dissociations. J. Am. Soc. Mass Spectrom. 2004, 15, 1869-1873. 
60. Zubarev, R. A.; Witt, M.; Baykut, G. Twofold Efficiency Increase by Selective Excitation of Ions for Consecutive Activation by Ion-Electron Reactions and Vibrational Excitation in Tandem Fourier Transform Ion Cyclotron Resonance Mass Spectrometry. Anal. Chem. 2005, 77, 29922996.

61. Emmett, M. R.; Tsybin, Y. O.; Haselmann, K. F.; Hendrickson, C. L.; Marshall, A. G. Observation of Charge Localization Effect on Electron Capture Dissociation Fragmentation Pattern. Proceedings of the 53rd ASMS Conference on Mass Spectrometry and Allied Topics; San Antonio, TX, June, 2005; DVD-ROM.

62. Liu, H.; Håkansson, K. Electron Capture Dissociation of Peptide-ProtonMetal Dication Complexes. Proceedings of the 53rd ASMS Conference on Mass Spectrometry and Allied Topics; San Antonio, TX, June, 2005; DVD-ROM.

63. Gill, A. C.; Jennings, K. R.; Wyttenbach, T.; Bowers, M. T. Conformations of Biopolymers in the Gas Phase: A New Mass Spectrometric Method. Int. J. Mass Spectrom. 2000, 195/196, 685-697.

64. Adams, C. M.; Zubarev, R. A. Electron Capture Dissociation Distinguishes a Single D-Amino Acid in a Protein and Probes the Tertiary Structure. J. Am. Soc. Mass Spectrom. 2004, 15, 1087-1098.

65. Strittmatter, E. F.; Lemoff, A. S.; Williams, E. R. Structure of Cationized Glycine, $\mathrm{Gly}-\mathrm{M} 2+(\mathrm{M}=\mathrm{Be}, \mathrm{Mg}, \mathrm{Ca}, \mathrm{Sr}, \mathrm{Ba})$ in the Gas Phase: Intrinsic Effect of Cation Size on Zwitterion Stability. J. Phys. Chem. A 2000, 104, 9793-9796.

66. Jockusch, R. A.; Price, W. D.; Williams, E. R. Structure of Cationized Arginine $(\mathrm{Ar}-\mathrm{M}+\mathrm{M}=\mathrm{H}, \mathrm{Li}, \mathrm{Na}, \mathrm{K}, \mathrm{Rb}$, and $\mathrm{Cs})$ in the Gas Phase:
Further Evidence for Zwitterionic Arginine. J. Phys. Chem. A 1999, 103, 9266-9274.

67. Breuker, K.; McLafferty, F. W. Native Electron Capture Dissociation for the Structural Characterization of Noncovalent Interactions in Native Cytochrome c. Angew. Chem. Int. Ed. 2003, 42, 4900-4904.

68. Breuker, K.; Oh, H.; Horn, D. M.; Cerda, B. A.; McLafferty, F. W. Detailed Unfolding and Folding of Gaseous Ubiquitin Ions Characterized by Electron Capture Dissociation. J. Am. Chem. Soc. 2002, 124, 6407-6420.

69. Horn, D. M.; Breuker, K.; Frank, A. J.; McLafferty, F. W. Kinetic Intermediates in the Folding of Gaseous Protein Ions Characterized by Electron Capture Dissociation Mass Spectrometry. J. Am. Chem. Soc. 2001, 123, 9792-9799.

70. Håkansson, K.; Liu, H.; Yang, J.; Adamson, J. T. Electron Capture Dissociation of Biological Molecules Complexed with Metal Ions. Proceedings of the 54th ASMS Conference on Mass Spectrometry and Allied Topics, Seattle, WA, May/June, 2006; DVD-ROM.

71. Lavanant, H.; Virelizier, H.; Hoppilliard, Y. Reduction of Copper(II) Complexes by Electron Capture in an Electrospray Ionization Source. J. Am. Soc. Mass Spectrom. 1998, 9, 1217-1221.

72. Bowers, M. T.; Liu, D.; Wyttenbach, T. Interaction of Divalent Metal Ions with the Hormone Oxytocin: Hormone Receptor Binding. Proceedings of the 54th ASMS Conference on Mass Spectrometry and Allied Topics, Seattle, WA, May/June, 2006; DVD-ROM.

73. Cooper, H. J.; Hudgins, R. R.; Håkansson, K.; Marshall, A. G. Characterization of Amino Acid Side-Chain Losses in Electron Capture Dissociation. J. Am. Soc. Mass Spectrom. 2002, 13, 241-249. 